\title{
A határérték bal kamrai ejekciós frakció együtt jár a mitralis anulus méretének és funkciójának eltéréseivel
}

\author{
Eredmények a báromdimenziós speckle-tracking \\ echokardiográfiás MAGYAR-Healtby Tanulmányból
}

\author{
Kovács Zsolt dr. ${ }^{1}$ - Kormányos Árpád dr. ${ }^{2}$ - Domsik Péter dr. ${ }^{2}$ \\ Kalapos Anita dr. ${ }^{2}$ - Lengyel Csaba dr. ${ }^{3}$ - Ajtay Zénó dr., \\ Forster Tamás dr. ${ }^{2}$. Nemes Attila dr. ${ }^{2}$ \\ 'Szent Rókus Kórház, Kardiológiai Osztály, Baja \\ Szegedi Tudományegyetem, Általános Orvostudományi Kar, Szent-Györgyi Albert Klinikai Központ, \\ ${ }^{2}$ II. Belgyógyászati Klinika és Kardiológiai Központ, ${ }^{3}$ I. Belgyógyászati Klinika, Szeged \\ ${ }^{4}$ Zsigmondy Vilmos Gyógyfürdőkórház, Harkány \\ ${ }^{5}$ Pécsi Tudományegyetem, Általános Orvostudományi Kar, Szívgyógyászati Klinika, Pécs
}

\begin{abstract}
Bevezetés: A mitralis anulus (MA) morfológiája és funkciója számos valvularis (például mitralis regurgitatióban) és nem valvularis betegségben (például bizonyos cardiomyopathiákban, cardialis amyloidosisban) eltéréseket mutathat. Célkitüzés: A jelen vizsgálat célja az MA morfológiai és funkcionális jellemzői és a háromdimenziós speckle-tracking echokardiográfíval (3DSTE) számított bal kamrai (BK) ejekciós frakció (EF) összefüggéseinek vizsgálata volt normális és határérték-BK-EF-fel bíró esetekben.

Módszer: A jelen vizsgálatba 146 olyan önkéntes eredményeit válogattuk be (átlagos életkor 32,0 $\pm 11,4$ év; 74 férfi), akiknél teljes körú kétdimenziós Doppler-echokardiográfiás vizsgálat történt negatív eredménnyel, melyet 3DSTEvel egészítettünk ki. A vizsgált populációt két további alcsoportra bontottuk a 3DSTE-vel számított BK-EF-nek megfelelóen (határérték $50-54 \%$ versus $\geq 55 \%$ ).

Eredmények: A határérték-BK-EF-fel bíró esetekben magasabb BK-i végszisztolés térfogatot és alacsonyabb BK-i longitudinális straint lehetett mérni. A végszisztolés és végdiasztolés MA-átmérő-, -area- és -kerület-értékek nagyobbnak bizonyultak a határérték-BK-EF-fel bíró esetekben, ekkor az MA funkcionális paraméterek is kisebbek voltak. A fenti összefüggések ellenére a BK-EF nem mutatott korrelációt sem a végszisztolés és végdiasztolés MA-méretekkel, sem az MA funkcionális paraméterekkel.

Következtetések: A 3DSTE-vel meghatározott határérték-BK-EF együtt jár az MA tágulásával és funkciójának romlásával.

Orv Hetil. 2018; 159(50): 2129-2135.
\end{abstract}

Kulcsszavak: bal kamra, ejekciós frakció, mitralis anulus, háromdimenziós echokardiográfia, speckle-tracking

\section{Borderline left ventricular ejection fraction is associated with alterations in} mitral annular size and function

\section{Results from the three-dimensional speckle-tracking echocardiographic MAGYAR-Healthy Study}

Introduction: Morphology and function of the mitral annulus (MA) shows alterations in different valvular (for instance in mitral regurgitation) and non-valvular disorders (for instance in certain cardiomyopathies, cardiac amyloidosis).

Aim: The aim of the present study was to examine the relationship between MA morphologic and functional properties and three-dimensional speckle-tracking echocardiography- (3DSTE) derived left ventricular (LV) ejection fraction $(\mathrm{EF})$ in subjects with normal versus borderline LV-EF. 
Method: The present study comprised 146 volunteers (mean age: $32.0 \pm 11.4$ years; 74 males) in whom complete two-dimensional Doppler echocardiography was performed with a negative result extended with 3DSTE. The population was further divided into two groups according to their 3DSTE-derived LV-EF (borderline $50-54 \%$ versus $\geq 55 \%$ ).

Results: In cases with borderline LV-EF, higher LV end-systolic LV volumes and lower LV longitudinal strain could be measured. All end-systolic and end-diastolic MA diameter, area and perimeter data proved to be higher in cases with borderline LV-EF. In these subjects, MA functional parameters proved to be lower as well. In contrast, LV-EF showed correlations neither with end-systolic and end-diastolic MA dimensions nor with MA functional parameters. Conclusions: 3DSTE-derived borderline LV-EF is associated with MA dilatation and functional impairment.

Keywords: left ventricle, ejection fraction, mitral annulus, three-dimensional echocardiography, speckle-tracking

Kovács Zs, Kormányos Á, Domsik P, Kalapos A, Lengyel Cs, Ajtay Z, Forster T, Nemes A. [Borderline left ventricular ejection fraction is associated with alterations in mitral annular size and function. Results from the three-dimensional speckle-tracking echocardiographic MAGYAR-Healthy Study]. Orv Hetil. 2018; 159(50): 2129-2135.

(Beérkezett: 2018. március 28.; elfogadva: 2018. július 17.)

\begin{abstract}
Rövidítések
$2 \mathrm{D}=($ two-dimensional $)$ kétdimenziós; $3 \mathrm{D}=$ (three-dimensional) háromdimenziós; 3DSTE $=$ (three-dimensional speckletracking echocardiography) háromdimenziós speckle-tracking echokardiográfia; ÁOK = Általános Orvostudományi Kar; $\mathrm{AP} 2 \mathrm{CH}=$ (apical 2-chamber view) csúcsi 2 üregi nézet; $\mathrm{AP} 4 \mathrm{CH}=($ apical 4 -chamber view $)$ csúcsi 4 üregi nézet; $\mathrm{BK}=$ bal kamra; $\mathrm{BP}=$ bal pitvar; $\mathrm{EF}=$ ejekciós frakció; $\mathrm{LS}=$ longitudinális strain; $\mathrm{MA}=$ mitralis anulus; $\mathrm{MAA}=\mathrm{MA}$-area $\mathrm{MAD}=$ (MA diameter) MA-átmérő; MAFAC = (MA fractional area change $)$ az MA frakcionális area változása; MAFS = (MA fractional shortening) MA frakcionális rövidülés; MAGYARHealthy Tanulmány = Motion Analysis of the heart and Great vessels bY three-dimensionAl speckle-tRacking echocardiography in Healthy subjects; MRI = (magnetic resonance imaging) mágnesesrezonancia-vizsgálat; RT3DE = (real-time threedimensional echocardiography) valósidejü3D-echokardiográfia; STE $=$ speckle-tracking echokardiográfia
\end{abstract}

A mitralis billentyú a bal pitvar (BP) és a bal kamra (BK) között elhelyezkedő nyereg alakú, komplex szerkezetú, háromdimenziós (3D-) struktúra, melynek szerepe többek között a vér egyirányú áramlásának biztosítása [ 1 , 2]. Fontos alkotóelemei a mitralis anulus (MA), a billentyúlemezek, a papillaris izom és az ínhúrok [1, 2]. Amellett, hogy a billentyúlemezek az MA-hoz rögzülnek, annak szerepe van a BP és a BK telődésének és ürülésének támogatásában is [3]. Ismert tény, hogy az MA morfológiája és funkciója számos valvularis kórképben (például mitralis prolapsusban, mitralis regurgitatio esetén) és nem valvularis betegségben (például bizonyos cardiomyopathiákban, cardialis amyloidosisban) eltéréseket mutathat [4-7]. A fentieknek megfelelően az MA méretének és funkciójának eltérései fontos paraméterek lehetnek a BK méretének és funkciójának változásával járó kórállapotok fennállása esetén azok megítélésében.

A háromdimenziós speckle-tracking echokardiográfia (3DSTE) olyan új noninvazív képalkotó eljárás, mely alkalmas nemcsak bizonyos szívüregek (például a BK, BP) egyidejú volumetrikus és strainalapú funkcionális megítélésére, hanem egyazon 3D virtuális modellt felhasználva egyszerúen lemérhetốk az MA szívciklusnak megfelelő méretei is [8]. A jelen vizsgálat célja az MA morfológiai és funkcionális jellemzői és a BK szisztolés pumpafunkcióját jellemző, 3DSTE-vel számított ejekciós frakció (EF) összefüggéseinek vizsgálata volt normális és határérték-BK-EF-fel bíró esetekben.

\section{Betegek és módszer}

\section{A vizsgált betegcsoport}

A jelen vizsgálatba 146 olyan önkéntest válogattunk be (átlagos életkor 32,0 $\pm 11,4$ év; 74 férfi), akiknél negatív eredményú teljes körú kétdimenziós (2D) Dopplerechokardiográfiás vizsgálat történt. Valamennyi esetben a rutin echokardiográfiás vizsgálatot 3DSTE-vel egészítettük ki. A betegek a vizsgálatok idején panaszmentesek voltak, nem volt ismert cardiovascularis betegségük vagy rizikófaktoruk, gyógyszert nem szedtek. A betegek csoportját két további alcsoportra bontottuk annak megfelelően, hogy a 3DSTE-vel számított BK-EF a teljesen normális tartományba esett-e (BK-EF $\geq 55 \%)$, vagy határértékúnek bizonyult (BK-EF $=\mathbf{5 0 - 5 4 \% )}$. A jelen vizsgálat a része a Szegedi Tudományegyetem, ÁOK, II. Belgyógyászati Klinika és Kardiológiai Központban megszervezett MAGYAR-Healthy Tanulmánynak (Motion Analysis of the heart and Great vessels bY three-dimensionAl speckle-tRacking echocardiography in Healthy subjects), melynek célja többek között a 3DSTE-vel mért paraméterek normálértékeinek meghatározása mellett fiziológiás összefüggések feltárása egészségesekben. Valamennyi esetben a vizsgálatban részt vevôk aláírták a beleegyező nyilatkozatot, a vizsgálati protokoll megfelelt az 1975-ös Helsinki Nyilatkozatban foglaltaknak, és a helyi intézeti etikai bizottság is elfogadta. 


\section{Kétdimenziós echokardiográfia}

Valamennyi esetben 2D Doppler-echokardiográfiás vizsgálat történt, melyhez Toshiba Artida ${ }^{\mathrm{TM}}$ echokardiográfiás készüléket használtunk (Toshiba Medical Systems, Tokió, Japán) 1-5 MHz-es PST-30SBP phased-array transzducerrel. A nemzetközi szakmai irányelvekkel összhangban lemértük a szívciklusnak megfelelő BK-i dimenziókat és térfogatértékeket, valamint a BP-i átmérōt [9]. A valvularis regurgitatiók kizárására színes Dopplerechokardiográfia és vizuális becslés történt, míg a billentyưgradiensek megítélésére folyamatos hullámú Doppler-technikát alkalmaztunk.

\section{Háromdimenziós speckle-tracking echokardiográfia}

A vizsgálatok elvégzéséhez ugyanazt a Toshiba Artida ${ }^{\mathrm{TM}}$ echokardiográfiás készüléket használtuk 3DSTE során, azonban a 3D echokardiográfiás adatbázisok digitális begyưjtéséhez PST-25SX mátrix phased-array transzducert alkalmaztunk apicalis pozícióból (Toshiba Medical
Systems, Tokió, Japán). Az egy lélegzetvételnyi idő és hat szívciklus alatt begyüjtött 3D-részadatbázisokból a szoftver teljes 3D echokardiográfiás adatbázist hozott létre. A vizsgáló az adatok begyújtése során az optimális képminőség eléréséhez a szükségleteknek megfelelően a mélységet és a szöget optimalizálta.

Az offline kvantitatív analízishez a 3D Wall Motion Tracking szoftver 2.7 verzióját használtuk (Toshiba Artida ${ }^{\mathrm{TM}}$; Toshiba Medical Systems, Tokió, Japán) [8, 10]. A szoftver a begyújtött 3D echokardiográfiás adatbázisok felhasználásával automatikusan a BK különböző szintjeiben három keresztmetszeti képet, valamint apicalis 2 üregi (apical 2-chamber view, $\mathrm{AP} 2 \mathrm{CH}$ ) és 4 üregi $(\mathrm{AP} 4 \mathrm{CH})$ hossztengelyi nézeteket hozott létre. A virtuális BK-i 3D-modellalkotáshoz szükség van az endocardialis felszín detektálására, amihez a vizsgáló $\mathrm{AP} 2 \mathrm{CH}$ - és $\mathrm{AP} 4 \mathrm{CH}$-nézetben definiálta az MA végpontjait és a $\mathrm{BK}$ csúcsát. Ezután a szoftver az endocardiumot automatikusan felismerte, majd rekonstruálta a szívciklusnak megfelelően. Vizsgálataink során a BK-i modell segítségével a volumetrikus adatokon túl a globális és átlagos szegmentális BK-i longitudinális strain (LS) paramétereket is kiszámítottuk (1.ábra).

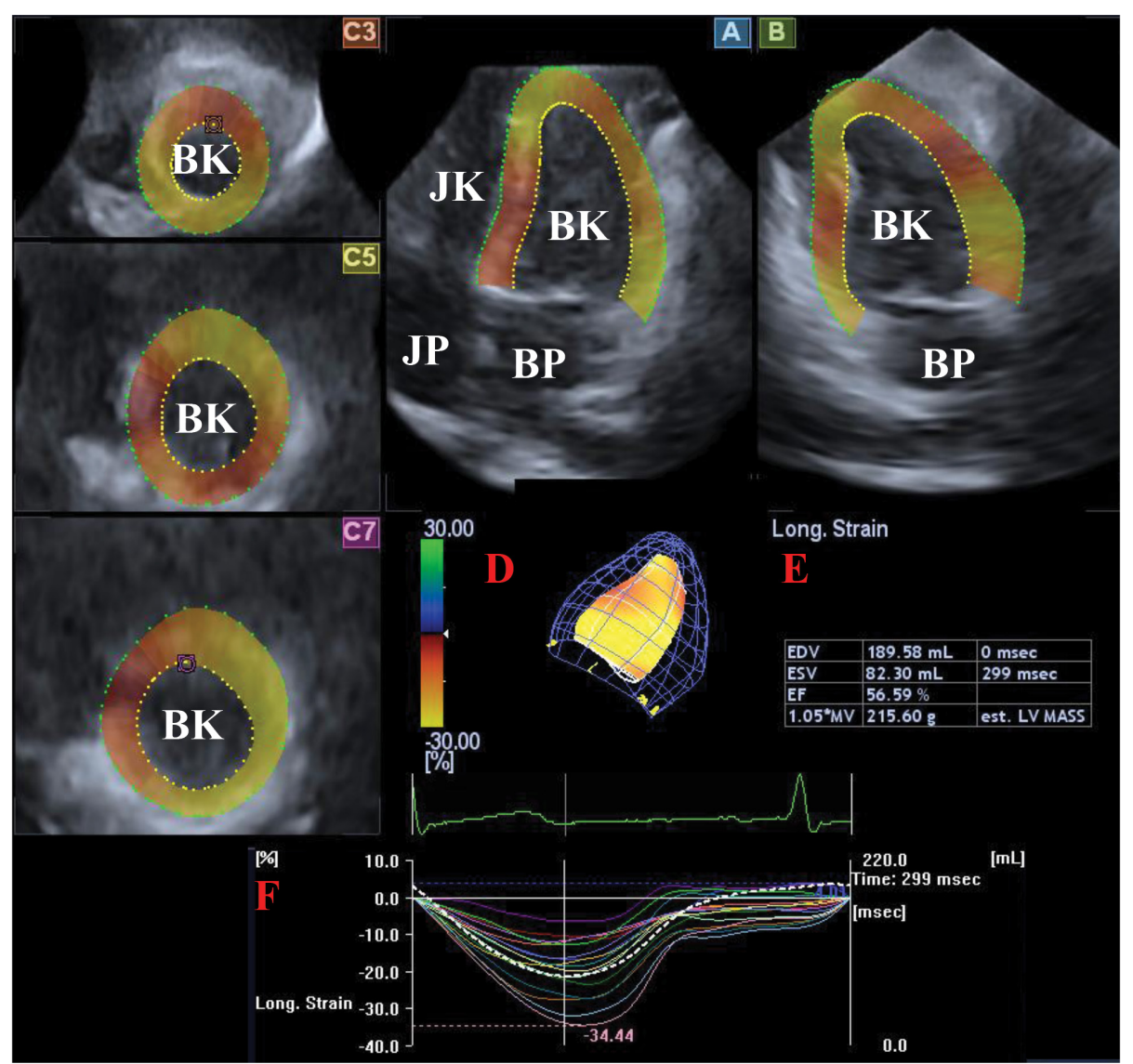

l. ábra $\quad$ Háromdimenziós (3D) speckle-tracking echokardiográfia során begyüjtött 3D-adatbázis felhasználásával a speciális szoftver segítségével a bal kamra (BK) apicalis négyüregi (A) és kétüregi (B), valamint három különböző síkban elkészített keresztmetszeti nézete (C3, C5, C7) ábrázolható. A módszer lehetővé teszi a BK 3D-s modelljének (piros D), volumetrikus adatainak (piros E) és a modell felhasználásával készített idő-BK-i térfogatnak (szaggatott vonal) és idő-BK-i szegmentális (longitudinális) straingörbéknek (színes vonalak) az egyidejü ábrázolását (piros F)

$\mathrm{BP}=$ bal pitvar; $\mathrm{BK}=$ bal kamra; $\mathrm{JP}=$ jobb pitvar; $\mathrm{JK}=$ jobb kamra 


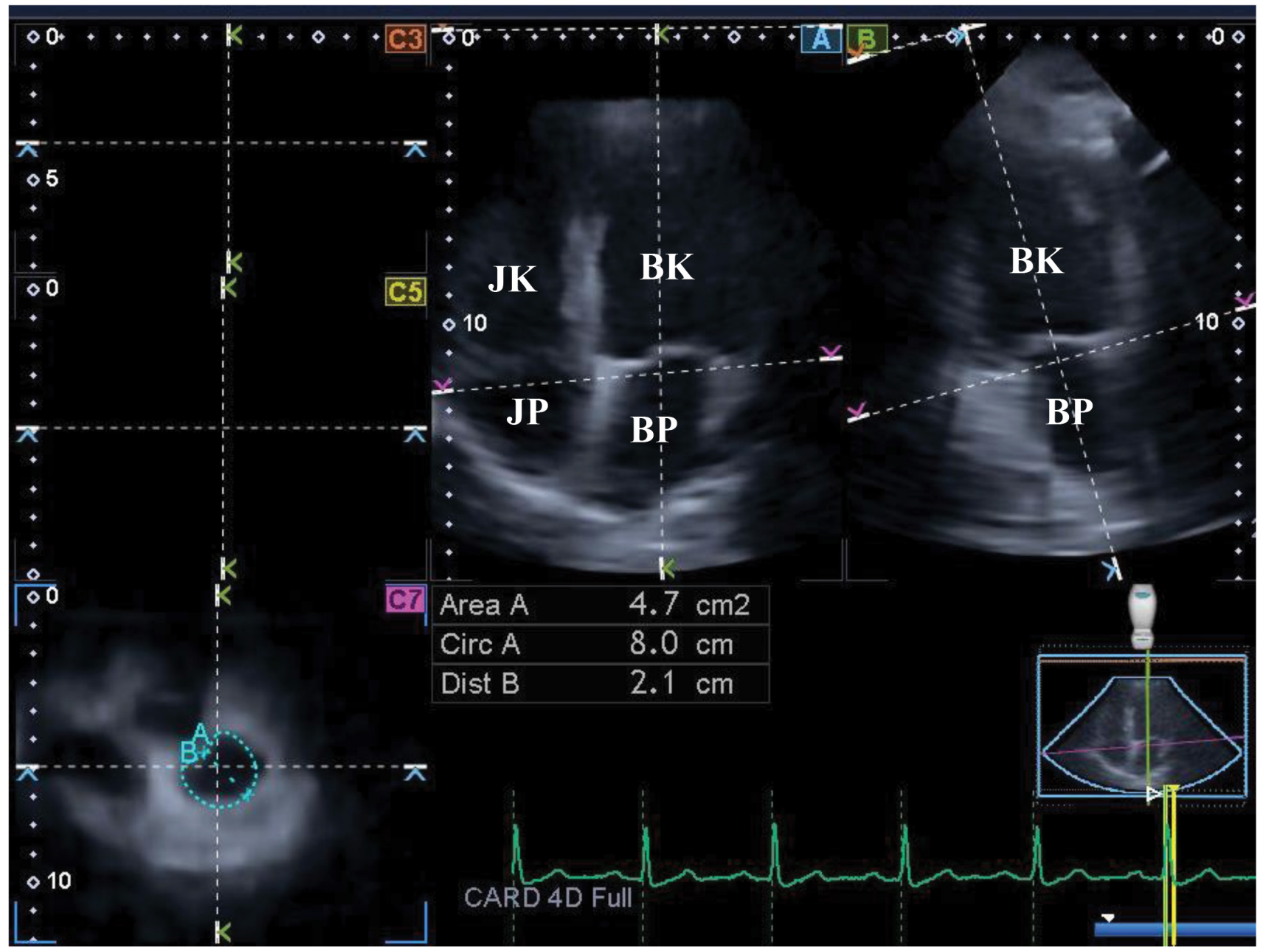

2. ábra

Háromdimenziós speckle-tracking echokardiográfia során létrehozott ábra: apicalis négyüregi nézet (A), apicalis kétüregi nézet (B) és keresztmetszeti nézet a mitralis anulus (MA) szintjében (C7), melyet az apicalis négyüregi és kétüregi nézetekben optimalizáltunk. A kétdimenziós síkba projektált nézeten az MA átmérője, areája és kerülete végdiasztolében és végszisztolében is lemérhető, majd a kapott paraméterekből az MA funkcióját jellemző értékek számíthatók

Area $=$ MA-area Circ $=$ MA-kerület; Dist $=$ MA-átmérő; $\mathrm{MA}=$ mitralis anulus; $\mathrm{BP}=$ bal pitvar; $\mathrm{BK}=$ bal kamra; $\mathrm{JP}=$ jobb pitvar; $\mathrm{JK}=$ jobb kamra

Az MA vizsgálata során a C7-es keresztmetszeti képen ábrázoltuk az MA-t végdiasztoléban és végszisztoléban úgy, hogy közben az AP4CH- és AP2CH-metszetek segítségével igyekeztünk megtalálni az MA optimális keresztmetszeti képét is. A módszer segítségével létrehozott 2D projekciós MA keresztmetszeti képen lemértük a valós MA-átmérőt, -areát és -kerületet végszisztoléban és végdiasztoléban, majd kiszámítottuk az MA funkcióját jellemző paramétereket (2. ábra).

MA morfológiai paraméterek:

- MA-átmérő (MAD), melyet végszisztoléban (a mitralis billentyű nyitódása előtt) és végdiasztoléban (a mitralis billentyű záródása előtt) mértünk;

- MA-area (MAA), melyet planimetria során mértünk végszisztoléban és végdiasztoléban;

- MA-kerület (MAK), melyet szintén planimetria során mértünk végszisztoléban és végdiasztoléban.
Az MA-funkció jellemzésére számított paraméterek:

- MA frakcionális rövidülés $($ MAFS) $=$ (végdiasztolés MAD - végszisztolés MAD) / (végdiasztolés MAD × 100)

- MA frakcionális area változása (MAFAC) = (végdiasztolés MAA - végszisztolés MAA) / (végdiasztolés MAA × 100)

\section{Statisztikai analizis}

Valamennyi értéket átlag \pm standard deviáció, vagy szám és százalék alakban tüntettük fel. A csoportok összehasonlítása során kétmintás t-próbát használtunk, míg a dichotom értékek összehasonlítására X-négyzet-próbát és Fisher-féle egzakt tesztet alkalmaztunk. Pearson-féle koefficienst számítottunk a korreláció jellemzésére. A p kisebb, mint 0,05-ot tekintettük statisztikailag szignifikánsnak. A statisztikai analízisek során MedCalc szoftvert használtunk (MedCalc, Mariakerke, Belgium). 


\section{Eredmények}

\section{Kétdimenziós Doppler-echokardiográfiás adatok}

2D echokardiográfia során normális cardialis méretek voltak mérhetők (bal pitvar: 39,5 $\pm 2,2 \mathrm{~mm}, \mathrm{BK}-\mathrm{i}$ végdiasztolés átmérő: $47,8 \pm 2,3 \mathrm{~mm}, \mathrm{BK}-\mathrm{i}$ végszisztolés átmérő: $33,1 \pm 2,2 \mathrm{~mm}$, interventricularis septum: $9,1 \pm$ 0,8 mm, BK-i hátsó fal: 9,0 \pm 0,7 mm, BK-EF: 64,5 \pm $2,2 \%)$. Egyik egészséges egyénnél sem volt igazolható egyes stádiumnál nagyobb mértékű valvularis regurgitatio vagy szignifikáns mértékú valvularis stenosis.

\section{Háromdimenziós speckle-tracking echokardiográfiás adatok}

A 3DSTE-vel mért BK-i volumetrikus, BK-LS- és MAadatokat az 1. táblázatban tüntettük fel. A határértékBK-EF-fel bíró esetekben nagyobb BK-i végszisztolés térfogatot és kisebb BK-LS-t lehetett mérni. A végszisztolés és végdiasztolés MA-átmérő-, -area- és -kerület-értékek nagyobbnak bizonyultak a határérték- (50-54\%) BK-EF-fel bíró betegekben a $\geq 55 \%$ BK-EF-fel bíró esetekhez képest. Ezekben az egyénekben az MA funkcionális paraméterek is kisebbnek bizonyultak.

\section{Korrelációk}

A teljes populációt vizsgálva a BK-EF nem mutatott korrelációt sem a végszisztolés és végdiasztolés $M A$-méretekkel, sem az MAFAC-cal $(\mathrm{r}=0,21, \mathrm{p}=0,24)$ és az MAFS-sal $(r=0,19, p=0,31)$. Hasonlóan nem volt korreláció igazolható az alcsoportok analízise során sem.

\section{Megbeszélés}

Az echokardiográfos vizsgálatok egyik legfontosabb indikációja a BK szisztolés pumpafunkciójának megítélése, melyre a leggyakrabban alkalmazott paraméter a BK-EF [10]. Ennek oka abban keresendő, hogy számos klinikai vizsgálat igazolta a BK-EF prognosztikus szerepét különböző betegcsoportokban [11]. A BK-EF számos echokardiográfiás módszer segítségével mérhető, beleértve az M-módú, 2D-, 2D speckle-tracking (STE), volumetrikus 3D-echokardiográfiás (RT3DE-) és 3DSTEeljárásokat [10]. A szakmai irányelvek szerint a jelenleg ajánlott 2D-echokardiográfiás módszer a BK-EF mérésére a módosított Simpson szerinti és az úgynevezett arealength módszerek $[9,10]$. Ugyanez a szakmai irányelv azt is megemlíti, hogy a RT3DE-alapú BK-EF-mérés pontos és reprodukálható, és amennyiben elérhető lehetőség, akkor használható [9].

Ismert tény, hogy a 2D-echokardiográfia alulbecsüli a valós MA-átmérőt, amennyiben azt az általunk bemutatott módszertanhoz hasonló, RT3DE és mágnesesrezonancia-vizsgálat (magnetic resonance imaging, MRI)
1. táblázat A háromdimenziós speckle-tracking echokardiográfia során mért bal kamrai volumetrikus és longitudinális strain, valamint mitralis anulus paraméterek összefüggései

\begin{tabular}{lccc}
\hline & Összes adat & $\begin{array}{c}\text { BK-EF } \\
50-54 \%\end{array}$ & $\begin{array}{c}\text { BK-EF } \\
\geq 55 \%\end{array}$ \\
\hline $\mathrm{n}$ & 146 & 33 & 113 \\
Kor (évek) & $32,0 \pm 11,4$ & $28,6 \pm 9,0^{*}$ & $33,0 \pm 11,9$ \\
Férfinem (\%) & $74(51)$ & $23(70)^{*}$ & $51(45)$ \\
\hline 3DSTE-vel mért BK-i volumetrikus adatok & & \\
\hline $\begin{array}{l}\text { BK-i végdiasztolés } \\
\text { térfogat (ml) }\end{array}$ & $87,0 \pm 23,9$ & $84,1 \pm 26,6$ & $87,8 \pm 23,1$ \\
$\begin{array}{l}\text { BK-i végszisztolés } \\
\text { térfogat (ml) }\end{array}$ & $36,4 \pm 10,8$ & $40,9 \pm 10,6^{*}$ & $35,1 \pm 10,5$ \\
BK-i ejekciós frakció (\%) & $58,5 \pm 5,3$ & $52,6 \pm 1,3^{*}$ & $60,3 \pm 4,8$ \\
\hline
\end{tabular}

3DSTE-vel mért BK-i strainadatok

BK-i globális longitudi- $\quad-16,0 \pm 2,5 \quad-15,0 \pm 2,3^{*} \quad-16,3 \pm 2,4$ nális strain $(\%)$

BK-i átlagos szegmen- $\quad-16,8 \pm 2,4 \quad-15,9 \pm 2,1 * \quad-17,1 \pm 2,4$ tális longitudinális

strain $(\%)$

3DSTE-vel mért MA-adatok

MA végdiasztolés $\quad 2,44 \pm 0,43 \quad 2,55 \pm 0,45 \dagger \quad 2,40 \pm 0,42$ átmérő $(\mathrm{cm})$

MA végdiasztolés area $\quad 7,31 \pm 2,21 \quad 7,90 \pm 2,61 \dagger \quad 7,13 \pm 2,06$ $\left(\mathrm{cm}^{2}\right)$

MA végdiasztolés $10,2 \pm 1,5 \quad 10,6 \pm 1,7 \dagger \quad 10,1 \pm 1,4$ kerület $(\mathrm{cm})$

MA végszisztolés $\quad 1,60 \pm 0,39 \quad 1,79 \pm 0,40 * \quad 1,54 \pm 0,37$ átmérő $(\mathrm{cm})$

MA végszisztolés area $\quad 3,45 \pm 1,27 \quad 4,21 \pm 1,34^{*} \quad 3,23 \pm 1,16$ $\left(\mathrm{cm}^{2}\right)$

MA végszisztolés $\quad 7,06 \pm 1,23 \quad 7,82 \pm 1,25^{*} \quad 6,84 \pm 1,14$ kerület $(\mathrm{cm})$

MA frakcionális area $\quad 51,5 \pm 15,5 \quad 44,7 \pm 14,8^{*} \quad 53,6 \pm 15,1$ változása $(\%)$

MA frakcionális rövidülés (\%)

${ }^{*} \mathrm{p}<0,05$ versus $\mathrm{BK}-\mathrm{EF} \geq 55 \%$

$\mathrm{tp}=0,06$ versus $\mathrm{BK}-\mathrm{EF} \geq 55 \%$

3DSTE = háromdimenziós speckle-tracking echokardiográfia; $\mathrm{BK}=$ bal kamra; $\mathrm{EF}=$ ejekciós frakció; $\mathrm{MA}=$ mitralis anulus

során mért értékekhez hasonlítjuk $[12,13]$. A 3Dechokardiogáfiás módszer pontosnak tekinthető, és jól korrelál az MRI-vel mérhető értékekkel [13]. Mivel az MA nem igazi kör alakú képlet, inkább D betúhöz hasonlít, és bizonyos betegségekben torzul, 'gömbölyödik', az MA-átmérőből származtatott paraméterek további torzulást mutathatnak (MA-area, -kerület). Ezen tények ráirányíthatják a figyelmet az echokardiográfiás 3D-képalkotás fontosságára még akkor is, ha a bemutatott módszertan nem veszi számításba az MA 3D-s nyereg alakját, csak annak 2D-be projektált képét.

A 3DSTE egy új, noninvazív diagnosztikus eljárás, mely egyesíti a volumetrikus 3D echokardiográfia és az 
STE előnyeit. Egy szívüregről (jelen esetben BK-ról) kreált virtuális 3D-modell segítségével a szívciklusnak megfelelően a BK volumetrikus és strainparaméterei egyidejüleg számíthatók [8]. Kleijn és mtsai szerint habár a 3DSTE-vel mért BK-i térfogatok kisebbek az MRI során mértekhez képest, a BK-EF tökéletes egyezést mutat [14]. Igazolást nyert az is, hogy a BK-i térfogatok és a BK-EF mérésében a 3DSTE megbízható [15], és a mért adatok a RT3DE-vel számítottal kicserélhetők [16]. A nemzetközi ajánlások alapján a $2 \mathrm{D}$-echokardiográfia során meghatározott $\mathrm{BK}-\mathrm{EF}$ határértéke $\geq 55 \%$ [9], míg irodalmi adatok alapján 3D-echokardiográfiával mérve a határérték $47-55 \%$ körüli, életkori és nembeli függést is mutat [17]. Irodalmi adatok alapján az is elmondható, hogy az 50\% alatti BK-EF csökkentnek tekinthető. A fenti tények figyelembevételével a 3DSTE-vel meghatározott 50-54\%-os BK-EF-et borderline, határterületi értéknek tarthatjuk.

A jelen vizsgálatban a BK-EF és az MA morfológiájának és funkciójának összefüggéseit vizsgáltuk. Ebből a célból két populációt hoztunk létre, az elsőben határérték 50-54\%-os BK-EF volt mérhető 3DSTE segítségével, míg a másodikban a BK-EF nagyobb-egyenlő volt 55\%-nál. Eredményeink azt igazolták, hogy a határértékBK-EF-fel bíró esetekben a szívciklustól függetlenül az MA tágabb, és funkciója rosszabb a 3DSTE-vel mérve normális tartományba eső BK-EF-fel bíró esetekhez képest. Ez az eredmény rávilágít arra a tényre, hogy a BKfunkció normalitásának határán mozgó esetekben már korán megfigyelhető az MA remodellációja. Ennek oka a a szívüregi volumetrikus változások mellett a BK, és feltételezhetően a BP funkcionális eltéréseiben is keresendő, ahogy ezt a szubklinikusan alacsonyabb BK-i globális LS csökkenése is jelzi. Saját anyagunkban a határértékBK-EF-et mutató betegekben további vizsgálatok elvégzését tartottuk szükségesnek az esetleges szubklinikus eltérések okának felderítése céljából. A fentieknek megfelelően további vizsgálatok szükségesek a fenti fiziológiai tények még komplexebb megértéséhez.

\section{A vizsgálat korlátai}

Vizsgálatunk elvégzésekor számos limitációs tényező merült fel, melyek közül az alábbiakat tartjuk a legfontosabbnak:

- A 3DSTE olyan új klinikai eljárás, mely jelenleg még széles körben nem terjedt el. A jelenleg rendelkezésre álló eszközök mellett a 2D-echokardiográfiához képest csökkent térbeli és időbeli felbontóképességgel rendelkezik, ami eredményeinket befolyásolhatta [8, 10].

- A jelen vizsgálat nem tekintette céljának a 3DSTE-vel mért BK-i volumetrikus adatok és BK-EF-mérés validálását $[10,18]$. Fontos tudni, hogy direkt validációs vizsgálat eddig még nem történt, mely a $2 \mathrm{D}$-echokardiográfiával (például Teichholz- vagy Simpson-módszerrel) számított BK-i volumeneket és EF-et a
3DSTE-vel számítottéhoz hasonlította volna. Eddig validációs vizsgálatok cardialis MRI-vel [14] és RT3DE-vel [16] szemben történtek.

- Saját tapasztalataink alapján a jelenleg elérhető 3DSTE-rendszerrel átlagosan 6-8\%-kal alacsonyabb BK-EF mérhető a 2D-echokardiográfiás Teichholz-féle módszerrel számítotthoz képest. Ennek megfelelően a 3DSTE-vel mért 50-54\%-os BK-EF-csoportba sorolt eseteink 2D-echokardiográfiával mért BK-EF-je valamennyi esetben $55 \%$ felett volt.

- 3DSTE segítségével nemcsak a BK, de a pitvarok volumetrikus és strainadatai is korrekt módon mérhetők a szívciklusnak megfelelően, ezek analízisét azonban ebben a tudományos múben nem vizsgáltuk [18].

- Az alcsoportok analízise során különbségeket találtunk az életkor és a nembeli eloszlásban, melyek eredményeinket befolyásolhatták.

\section{Következtetések}

A 3DSTE-vel meghatározott határérték-BK-EF együtt jár az MA tágulásával és funkciójának romlásával.

Anyagi támogatás: A közlemény megírása anyagi támogatásban nem részesült.

Szerzôi munkamegosztás: K. Zs., K. Á.: A hipotézisek kidolgozása, vizsgálat lefolytatása, statisztikai elemzések, a kézirat megszövegezése. D. P., K. A.: A vizsgálatok lefolytatása. L. Cs., A. Z., F. T.: A kézirat megszövegezése. N. A.: A hipotézisek kidolgozása, a kézirat megszövegezése. A cikk végleges változatát valamennyi szerző elolvasta és jóváhagyta.

Érdekeltségek: A szerzőknek nincsenek érdekeltségeik.

\section{Irodalom}

[1] Dal-Bianco JP, Levine RA. Anatomy of the mitral valve apparatus - role of 2D and 3D echocardiography. Cardiol Clin. 2013; 31: $151-164$.

[2] Nemes A, Geleijnse ML, Soliman OI, et al. Evaluation of the mitral valve by transthoracic real-time three-dimensional echocardiography. [A mitralis billentyú vizsgálata transthoracalis realtime háromdimenziós echokardiográfiával.] Orv Hetil. 2010; 151: 854-863. [Hungarian]

[3] Silbiger JJ. Anatomy, mechanics, and pathophysiology of the mitral annulus. Am Heart J. 2012; 164: 163-176.

[4] Apor A, Nagy AI, Kovács A, et al. Three-dimensional dynamic morphology of the mitral valve in different forms of mitral valve prolapse - potential implications for annuloplasty ring selection. Cardiovasc Ultrasound 2016; 14: 32.

[5] Antoine C, Mantovani F, Benfari G, et al. Pathophysiology of degenerative mitral regurgitation: new 3-dimensional imaging insights. Circ Cardiovasc Imaging 2018; 11: e005971.

[6] Nemes A, Anwar AM, Caliskan K, et al. Non-compaction cardiomyopathy is associated with mitral annulus enlargement and functional impairment: a real-time three-dimensional echocardiographic study. J Heart Valve Dis. 2008; 17: 31-35. 
[7] Nemes A, Földeák D, Kormányos Á, et al. Cardiac amyloidosis associated with enlargement and functional impairment of the mitral annulus: insights from the three-dimensional speckle tracking echocardiographic MAGYAR-Path Study. J Heart Valve Dis. 2017; 26: 304-308.

[8] Nemes A, Kalapos A, Domsik P, et al. Three-dimensional speckle-tracking echocardiography - a further step in non-invasive three-dimensional cardiac imaging. [Háromdimenziós speckletracking echokardiográfia - egy újabb lépés a noninvazív háromdimenziós kardiális képalkotásban.] Orv Hetil. 2012; 153: 1570-1577. [Hungarian]

[9] Lang RM, Badano LP, Mor-Avi V, et al. Recommendations for cardiac chamber quantification by echocardiography in adults: an update from the American Society of Cardiology and European Association of Cardiovascular Imaging. J Am Soc Echocardiogr. 2015; 28: 1-39.el4.

[10] Nemes A, Forster T. Recent echocardiographic examination of the left ventricle - from M-mode to $3 \mathrm{D}$ speckle-tracking imaging. [A bal kamra korszerú echokardiográfiás vizsgálata - az Mmódtól a 3D speckle-tracking képalkotásig.] Orv Hetil. 2015; 156: 1723-1740. [Hungarian]

[11] Prastaro M, Pirozzi E, Gaibazzi N, et al. Expert review on the prognostic role of echocardiography after acute myocardial infarction. J Am Soc Echocardiogr. 2017; 30: 431-443.e2.

[12] Anwar AM, Soliman OI, ten Cate FJ, et al. True mitral annulus diameter is underestimated by two-dimensional echocardiography as evidenced by real-time three-dimensional echocardiography and magnetic resonance imaging. Int J Cardiovasc Imaging 2007; 23: 541-547.

[13] Anwar AM, Soliman OI, Nemes A, et al. Assessment of mitral annulus size and function bv real-time 3 -dimensional echocardi- ography in cardiomyopathy: comparison with magnetic resonance imaging. J Am Soc Echocardiogr. 2007; 20: 941-948.

[14] Kleijn SA, Brouwer WP, Aly MF, et al. Comparison between three-dimensional speckle-tracking echocardiography and cardiac magnetic resonance imaging for quantification of left ventricular volumes and function. Eur Heart J Cardiovasc Imaging 2012; 13: 834-839.

[15] Kleijn SA, Aly MF, Terwee CB, et al. Reliability of left ventricular volumes and function measurements using three-dimensional speckle tracking echocardiography. Eur Heart J Cardiovasc Imaging 2012; 13: 159-168.

[16] Kleijn SA, Aly MF, Terwee CB, et al. Comparison between direct volumetric and speckle tracking methodologies for left ventricular and left atrial chamber quantification by three-dimensional echocardiography. Am J Cardiol. 2011; 108: 1038-1044.

[17] Wood PW, Choy JB, Nanda NC, et al. Left ventricular ejection fraction and volumes: it depends on the imaging method. Echocardiography $2014 ; 31: 87-100$.

[18] Piros GÁ, Domsik P, Kalapos A, et al. Relationships between right atrial and left ventricular size and function in healthy subjects. Results from the three-dimensional speckle-tracking echocardiographic MAGYAR-Healthy Study. [A jobb pitvar és a bal kamra méretének és funkciójának összefüggései egészségesekben. Eredmények a háromdimenziós speckle-tracking echokardiográfiás MAGYAR-Healthy Tanulmányból.] Orv Hetil. 2015; 156: 972-978. [Hungarian]

(Nemes Attila dr., Szeged, Semmelweis u. 8., 6725 e-mail: nemes@in2nd.szote.u-szeged.hu )

\section{„A józan ész nem ajándék, hanem büntetés, mert meg kell küzdened azokkal, akik nem rendelkeznek vele." (Albert Einstein)}

